\title{
International Humanitarian Law as a Source of Protection for Refugees from Areas of Armed Conflict
}

\author{
Karoline Kerber
}

\begin{abstract}
The primary focus of attention in discussions on legal norms protecting refugees are usually the 1951 Geneva Convention relating to the Status of Refugees and more recently international human rights instruments, such as the European Convention on Human Rights. In the context of armed conflicts, however, it seems natural to think of international humanitarian law as applicable in armed conflicts. This article examines the potential of international humanitarian law, i.e. the four Geneva Conventions of 1949 and their additional protocols of 1977, as sources of legal protection for refugees who seek shelter outside their home country.
\end{abstract}

\section{Précis}

Les textes légaux de référence sur lesquels l'attention se porte dans les discussions à propos des normes juridiques en matière de protection des réfugiés sont la Convention de Genève relative au Statut des Réfugiés de 1951 et, plus récemment, la Convention Européenne sur les Droits de l'Homme et autres mécanismes internationaux pour les droits humains. Dans le contexte des confrontations armés cependant, il semble naturel de concevoir les lois internationales en matières humanitaires comme continuant de s'appliquer dans le conflit. Cet article examine le potentiel des lois internationales en matières humanitaires, nommément les quatre Conventions de Geneve de 1949 et leurs protocoles additionnels de 1977, comme sources de protection légale pour les réfugiés qui recherchent un abri hors de leurs foyer.

Karoline Kerber, LL.M., is a Ph.D. candidate and Research Assistant at the Centre for International and European Law on Immigration and Asylum, University of Konstanz, Konstanz, Germany.
In discussions concerning the legal protection of people fleeing areas of armed conflict, the primary focus of attention is usually the 1951 Geneva Convention relating to the Status of Refugees. ${ }^{1}$ Recently, some consideration has also been given to human rights instruments, such as the European Convention on Human Rights. It is the aim of this article to examine how far international humanitarian law, i.e. the four Geneva Conventions of $1949,{ }^{2}$ the two Additional Protocols of $1977,{ }^{3}$ and the law of The Hague ${ }^{4}$ can serve as a source of protection for the victims of armed conflicts who search for protection abroad. The following explanations distinguish non-international from international armed conflicts.

\section{Non-International Armed Conflicts}

\section{Article 3 Common to the Four Geneva Conventions of 1949}

In case of a non-international armed conflict on the territory of a contracting state of the four Geneva Conventions of 12 August 1949, each party to the conflict, pursuant to Article 3 common to all four Geneva Conventions of 1949 , has to observe certain rules concerning the treatment of the civil population, the injured, and the sick. The provision does not contain any obligations for third states, such as reception or nonrefoulement of refugees. Such obligations are neither expressly set down in the wording of Article 3 nor can they be derived by way of interpretation. ${ }^{5}$ The rules contained in Article 3 common to the four 1949 Geneva Conventions form part of "general principles of humanitarian law to which the Conventions merely give specific expression." ${ }^{6}$ They represent peremptory norms to be followed in non-international as well as in international armed conflicts. Also, by virtue of Article 1 of the Geneva Conventions, the contract- ing parties have to "respect" the Conventions and even "to ensure respect" for them "in all circumstances." Third states are therefore under an obligation not to encourage persons or groups engaged in the conflict to act in violation of the provisions of Article 3 common to the four Conventions. ${ }^{7}$ However, these general principles of law, and in particular the duty following from Article 1 common to all Geneva Conventions to ensure respect for the Conventions, do not create a duty of non-refoulement for states not involved in the conflict. ${ }^{8}$

\section{Protocol II Additional to the Geneva Conventions}

Protocol II, ${ }^{9}$ according to its Article 1 (1), applies to all non-international armed conflicts that take place in the territory of a High Contracting Party between its armed forces and dissident armed forces or other organized armed groups with a certain organization and power. Pursuant to Article 2, it protects all persons affected by an armed conflict of such kind. In the following provisions, those persons are guaranteed a certain treatment, while the civilian population and individual civilians pursuant to Article 13 are granted special protection through part IV of the Protocol. None of the provisions laid down in Protocol II contains obligations for third states not parties to the conflict. Even if one assumes that the rules set out in the additional protocols to the Geneva Conventions at least partly represent rules of customary international law, ${ }^{10}$ and therefore do not bind only the contracting parties, these customary norms do not bind third states and do not contain a principle of non-refoulement. ${ }^{11}$

\section{International Armed Conflicts}

For the case of international armed conflicts, neutral states ${ }^{12}$ are expressly 
provided with limited duties through the four Geneva Conventions and Additional Protocol I. ${ }^{13}$

\section{Article 4 of the 1st Geneva}

Convention, Article 5 of the 2nd Geneva Convention and Article 19 Protocol I

Pursuant to Article 4 of the 1st Geneva Convention, ${ }^{14}$ Article 5 of the 2nd Geneva Convention, ${ }^{15}$ and Article 19 , Protocol I neutral powers shall apply, through analogy, the provisions of the respective Convention or Protocol I to the wounded, sick and shipwrecked, to members of the medical personnel, and to chaplains of the armed forces of the Parties to the conflict received or interned in their territory. This, however, does not imply a duty to receive any such person. A certain treatment is merely obligatory, in case a reception has already taken place. ${ }^{16}$

\section{Article 12 of the 1st and 2nd Geneva Conventions}

Pursuant to the respective Article 12 of the 1st and the 2nd Geneva Conventions, the persons listed above shall be respected and protected in all circumstances. Possibly, a duty not to refoule the protected persons from the territory of a receiving state could be deduced from this rule of respect and protection.

\section{Article 4 B (2) of the 3rd Geneva Convention}

Article 4 B (2) of the 3rd Geneva Convention ${ }^{17}$ obliges neutral and non-belligerent powers to treat prisoners of war whom they have already received on their territory according to the Convention. However, the provision does not contain a duty of reception towards the said persons. Also, the provisions on the repatriation and accommodation of certain prisoners of war, Articles 109 et seq., do not establish an obligation of reception for the neutral countries but only set down duties for the parties to the conflict.

\section{The 4th Geneva Convention}

Finally, the 4th Geneva Convention ${ }^{18}$ contains in its part II provisions on the protection of the whole of the populations of the countries in international conflicts, without any adverse distinction based, in particular, on race, nationality, religion or political opinion, which are intended to alleviate the sufferings caused by war. ${ }^{19}$ These rules are, however, only addressed to the parties to the conflict. ${ }^{20}$ They do not create duties for neutral states. In part III, the Convention confers certain rights pursuant to Article 27 et seq. to "persons protected by the Convention," i.e. those, who, pursuant to Article 4 (1), at a given moment and in any manner whatsoever, find themselves, in case of a conflict or occupation, in the hands of a Party to the conflict or Occupying Power of which they are not nationals. ${ }^{21}$ The 4th Geneva Convention does not set out an express obligation on third neutral states to refrain from indirectly exposing persons in search for protection within their territory to the danger of becoming the victim of a treatment prohibited by Article 27 et seq. through extradition, rejection at the frontier, or expulsion. In particular, no duty of third states to admit persons corresponds to the right to leave the territory of conflict under Article 35 of the 4th Geneva Convention. Article 44 of the 4th Geneva Convention concerns the treatment of refugees, but only refers to refugees already admitted to the territory of a party to the conflict. Equally, Article 45 only applies to "protected persons" according to Article $4^{22}$ and Article 70 (2) protects nationals of the occupying Power who, before the outbreak of hostilities, have sought refuge in the territory of the occupied State, i.e. not persons, who became refugees in the course of the present conflict. ${ }^{23}$ An interpretation of these provisions by the means provided for the interpretation of international treaties under public international law ${ }^{24}$ does not lead to an obligation of third neutral states not to indirectly expose protected persons to the danger of becoming victims of treatment contrary to Article 27 et seq. by way of an extradition, rejection at the frontier, or an expulsion. ${ }^{25}$

\section{The V. Hague Convention of 1907}

Finally, the V. Hague Convention of 1907 needs to be shortly reviewed: Chapter II of this international treaty deals with the treatment of belligerents interned and wounded in neutral territory. This rules does not establish any kind of reception duty. According to Article 12, the neutral power shall, in the absence of a special convention to the contrary, supply the interned with the food, clothing, and relief required by humanity. At the conclusion of peace, the expenses caused by the internment shall be made good.

\section{Conclusion}

Under international humanitarian law persons fleeing their home are only protected insofar as they are in the power of a party to the conflict. ${ }^{26}$ Therefore, one can say that international humanitarian law is not a fertile source of norms for the protection of persons fleeing armed conflict ${ }^{27}$ who seek protection outside their country of origin..$^{28}$ Especially, no international obligations going beyond those stemming from the Geneva Convention relating to the Status of Refugees, the European Convention on Human Rights and other international Human Rights treaties, arise from the four Geneva Conventions of 1949 and the additional protocols of 1977.

\section{Notes}

1. UNTS Vol. 189, 150.

2. Convention for the Amelioration of the Condition of the Wounded and Sick in Armed Forces in the Field of 12 August 1949 (UNTS Vol. 75, 31, 1st Geneva Convention). Convention for the Amelioration of the Condition of Wounded, Sick and Shipwrecked Members of Armed Forces at Sea of 12 August 1949 (UNTS Vol. 75, 85, 2nd Geneva Convention). Convention Relative to the Treatment of Prisoners of War of 12 August 1949 (UNTS Vol.75, 135,3rd Geneva Convention). Convention Relative to the Protection of Civilian Persons in Time of War of 12 August 1949 (UNTS Vol. 75, 287, 4th Geneva Convention).

3. Protocol Additional to the Geneva Conventions of 12 August 1949, and Relating to the Protection of Victims of International Armed Conflicts of 8 June 1977

(C) Karoline Kerber, 1997. This open-access work is licensed under a Creative Commons Attribution-NonCommercial 4.0 International License, which permits use, reproduction and distribution in any medium for non-commercial purposes, provided the original author(s) are credited and the original publication in Refuge: Canada's Journal on Refugees is cited. 
(Official Records of the Diplomatic Conference on the Reaffirmation and Deoelopment of International Humanitarian Law Applicable in Armed Conflicts, Geneva (1974-1977), Vol. I, Bern 1978, p. 115, Protocol I). Protocol Additional to the Geneva Conventions of 12 August 1949, and Relating to the Protection of Victims of Non-International Armed Conflicts of 8 June 1977 (ibid., 185, Protocol II).

4. In the context of this article regard will be had exclusively to the Convention of the Hague of 18 October 1907 Respecting the Rights and Duties of Neutral Powers and Persons in Case of War on Land (reprinted in D. Schindler, and J. Toman, The Laws of Armed Conflicts. A Collection of Conventions, Resolutions and Other Documents, Geneva 1988, p. 941, (V. Convention of The Hague of 1907).

5. But see R. Marx, in Aktuelle asylrechtliche Probleme der gerichtlichen Entscheidungspraxis in Deutschland, Osterreich und der Schweiz, edited by K. Barwig and W. Brill, p. 103, 129 referring to the ICJ in the case of Military and Paramilitary Activities in and against Nicaragua, ICJ Reports 1986, p. 14, 113 et seq.; M. Sternberg v., IJRL 5 (1993), 153, 172.

6. See the judgment of the ICJ in Military and Paramilitary Activities in and against Nicaragua, ICI Reports 1986, p. 14, 114, para. 220. Cf. also Commentary on the $\mathrm{Ge}$ neva Conventions of 12 August 1949: Geneva Convention for the Amelioration of the Wounded and Sick in Armed Forces in the Field, edited by J. Pictet, p. 38, 41; id., Principles of Humanitarian Law, p. 26; T. Meron, AJIL 81 (1987), 348, 362.

7. See the judgment of the ICJ in Military and Paramilitary Activities in and against Nicaragua, ICJ Reports 1986, p. 14, 114, para. 220.

8. In the Nicaragua case the ICJ held that the actions of the United States in and against Nicaragua fell under the legal rules relating to international conflicts (cf. ICJ Reports, p. 14, 114, paras. 218 and 219). The U.S. were held to be under an obligation pursuant to Art. 1 of the Geneva Conven- tions not to encourage persons or groups engaged in the conflict in Nicaragua to act in violation of the provisions of Art. 3. See also U.S. Court of Appeals of the 9th Circuit, in Echeveria-Hernandez v. INS, 923 F.2d 688 (9th Cir., 1991); U.S. Board of Immigration Appeals, in Matter of Medina, 19 I \& N Dec. 734 (BIA 1988), pp. 738-40.

9. For full name, see supra note 3.

10. See T. Meron, Human Rights and Humanitarian Norms as Customary Law, p. 65, 73; concerning Protocol I, see A. V. Lombardi, Bürgerkrieg und Völkerrecht, p. 310; similar S. R. Chowdhury, IJRL 7 (1995), 100, 109. As a consequence, these authors are in favor of applicability of Art. 4, 14, 17 and 18 (2) of Protocol II to internally displaced persons in situations below the threshold of an armed conflict.

11. Not convincing the opinion of R. Marx, in Aktuelle asylrechtliche Probleme der gerichtlichen Entscheidungspraxis in Deutschland, Osterreich und der Schweiz, edited by K. Barwig and W. Brill, pp. 103, 130,131 .

12. Art. 16 of the V. Convention of The Hague of 1907 (for full name see supra note 4) defines neutrals as nationals of a State which is not taking part in the war.

13. For full name, see supra note 3.

14. For full name, see supra note 2.

15. Ibid.

16. There is not such an obligation in international customary law either. For a disscussion view see R. Marx in Aktuelle asylrechtliche Probleme det gerichtlichen Entscheidungspraxis in Deutschland, Osterreich und der Schweiz, edited by K. Barwig, and W. Brill,pp.103, 130,131; See also supra note 11 and the text belonging to it.

17. For full name see, supra note 2.

18. Ibid.

19. See Art. 13 of the 4th Geneva Convention.

20. Article 23 (free passage of all consignments of medical and hospital stores and objects necessary for religious worship, foodstuffs, clothing and tonics) forms an exception. It envisages all contracting parties to the Convention.

21. Pursuant to Art. 73 Protocol I also persons who, before the beginning of hostilities, were considered as stateless persons or refugees under the relevant international instruments accepted by the Parties concerned or under the national legislation of the State of refuge or State of residence are protected persons within the meaning of Parts I and III of the 4th Geneva Convention.

22. See also O. Kimminich, AWR-Bull. 32 (1994), 160, 168; W. Kälin, Grundriss des Asylverfahrens, p. 207.

23. For explanations on this see also $K$. Obradovic, in Thesaurus Acroasium, pp. 131,150 , particularly note 40 and pp. 159 , 160; J. Patrnogic, UNHCR reprint from Ann. de Droit Int'l Méd. 7/1981, 95, 98 ff.; O. Kimminich, AWR-Bull. 32 (1994), 160, 166 et seq.

24. See Art. 31 et seq. of the Vienna Convention on the Law of Treaties.

25. See also the United States BIA in Matter of Medina, 19 I \& N Dec. 734 (BIA 1988), quoted in M. Sternberg v., IJRL 5 (1993), 153,171 . For a dissussion view see Parker, Immigration Newsletter 13 (May-June 1984), 6, 7. D. Perluss and J. F. Hartmann, Va. J. Int'l L 26 (1986), 551, 606, however, regard such an interpretation as "an ambitious one." W. Kälin, Grundriss des Asylverfahrens, p. 207, is of the opinion that, in view of the large number of states that have ratified the Geneva Conventions, these provisions do express a basic confession that foreigners originating in countries of conflict are worthy of protection.

26. See also J.-P. Lavojer, Rev. ICR 812 (March-April 1995), 183 at 189.

27. For an examination with regard to internally displaced persons see D. Plattner, Int'l Rev. Red Cross 291 (1992), 567-80.

28. See also Index of International Humanitarian Law, edited by W. A. Solf and J. A. Roach. $\square$

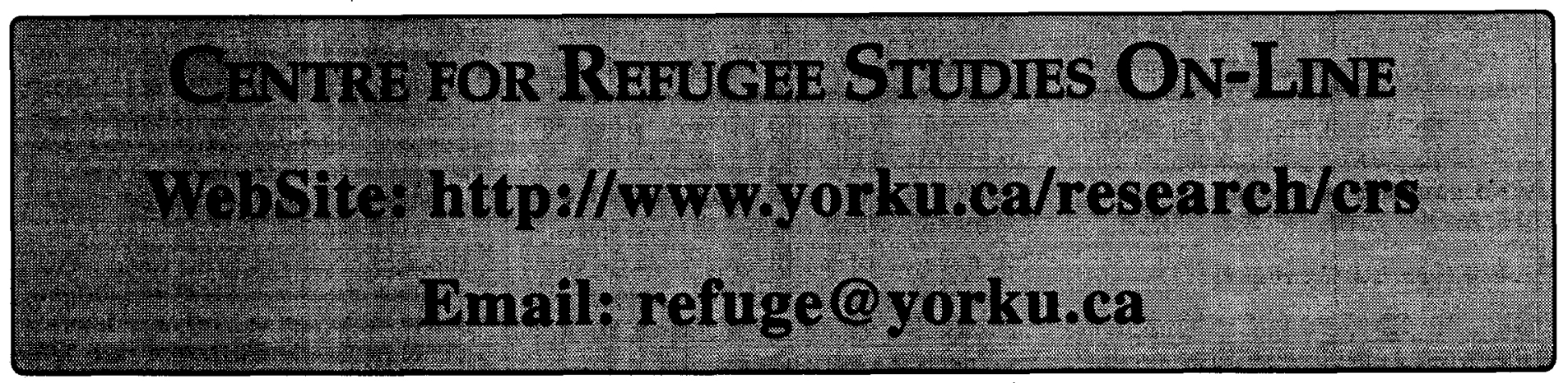

